E3S Web of Conferences 1, 01005 (2013)

DOI: $10.1051 / \mathrm{e} 3$ sconf/20130101005

(c) Owned by the authors, published by EDP Sciences, 2013

\title{
Risk-Based Approach for Thermal Treatment of Soils Contaminated with Heavy Metals
}

\author{
D. M. Cocârță ${ }^{1}$, R. N. Dinu ${ }^{2}$, C. Dumitrescu ${ }^{3}$, A.M. Reşetar-Deac ${ }^{4}$ and V. Tanasiev ${ }^{5}$ \\ ${ }^{1}$ Department of Energy Production and Use, Faculty of Power Engineering, POLITEHNICA University of Bucharest, \\ 313 Splaiul Independentei, 6th District, 006042, Bucharest, ROMANIA, dianacocarta13@yahoo.com \\ ${ }^{2}$ Department of Energy Production and Use, Faculty of Power Engineering, POLITEHNICA University of Bucharest, \\ 313 Splaiul Independentei, 6th District, 006042, Bucharest, ROMANIA, ramona.dinu@gmail.com \\ ${ }^{3}$ Department of Energy Production and Use, Faculty of Power Engineering, POLITEHNICA University of Bucharest, \\ 313 Splaiul Independentei, 6th District, 006042, Bucharest, ROMANIA, crisa_dumitrescu@yahoo.com \\ ${ }^{4}$ National Institute for Research and Development in Environmental Protection, 294 Splaiul Independentei, 6th District, \\ 060031,Bucharest,ROMANIA, ana6209@yahoo.com \\ ${ }^{5}$ Department of Energy Production and Use, Faculty of Power Engineering, POLITEHNICA University of Bucharest, \\ 313 Splaiul Independentei,6th District, 006042, Bucharest, ROMANIA, vadim_419@yahoo.com
}

\begin{abstract}
In the actual context of limited soil resources and the significant degree of environmental pollution, public administrations and authorities are interested in restoring contaminated sites paying attention to the impact of these soils on human health. This paper aims to present the efficiency of the the incineration as a method for treatment of the contaminated soils $t$ based on human health risk assessment. Through various experimentations, the following metals have been studied: $\mathrm{Zn}, \mathrm{Cu}, \mathrm{Fe}, \mathrm{Mn}, \mathrm{Ni}, \mathrm{Pb}, \mathrm{Cr}, \mathrm{Co}, \mathrm{Cd}, \mathrm{Hg}, \mathrm{As}$ and $\mathrm{Be}$. The most important and interesting results concerning both thermal treatment removal efficiency and associated human health risk assessments were achieved concerning $\mathrm{Cd}, \mathrm{Pb}$ and $\mathrm{Ni}$ contaminants. The behavior of Cadmium $(\mathrm{Cd})$, Lead $(\mathrm{Pb})$ and Nickel $(\mathrm{Ni})$ concentrations from heavy metals incineration soil has been analyzed for three incineration temperatures $\left(600^{\circ} \mathrm{C}, 800^{\circ} \mathrm{C}\right.$ and $\left.1000^{\circ} \mathrm{C}\right)$ and two resident times of soil within the incineration reactor ( $30 \mathrm{~min}$. and $60 \mathrm{~min}$.). In this case, the level of contaminants in the treated soil can be reduced but not enough to ensure an acceptable risk for human health.
\end{abstract}

Key words: Heavy metals, risk assessment, incineration, soil decontamination

\section{Introduction}

According to the European Environmental Agency Report, the EEA member countries had identified, in 2007, 250.000 contaminated sites in need of remediation (EEA, 2007). The growing awareness on environmental pollution together with more coherent legislation requirements on Romania's human health protection field increased the concern for the management of contaminated soils at national level.

Currently, Romania has about 900.000 ha of industrial polluted lands of which $70 \%$ are used for agricultural activities and which urgently need to be decontaminated. This paper presents some results achieved in the framework of the RECOLAND research project, co-financed under the Sectorial Operational Programme: "Increase of Economic Competitiveness".

RECOLAND project proposes an integrated approach for identifying appropriate solutions for decontamination of complex polluted soils (various types of pollutants as: PCBs, heavy metals, pesticides and PAHs), considering human risk assessment.

Incineration, pyrolysis, electroremediation, bioremediation and phytoremediation methods have been tested in a laboratory or at real scale using soil provided from one of the most polluted area of Europe - Romania. Since 1936, this area has been extensively contaminated by two industries: a plant where carbon black was produced until 1993; and a second one processing nonferrous metals like lead, zinc and cadmium from 1939 to 2009 (Szanto et. al., 2011).

This paper focuses on combustion as a decontamination method, and risk assessment before and after applying the thermal remediation methodology.

\section{Materials and Methods}

\subsection{Pilot plant description}

A rotary kiln pilot plant incinerator with a capacity of 
maximum $30 \mathrm{~kg} / \mathrm{h}$ of solid material has been used for the thermal treatment of the polluted soil (see Fig. 1) at three process temperatures: $600^{\circ} \mathrm{C}, 800^{\circ} \mathrm{C}$ and $1000^{\circ} \mathrm{C}$ and two residence times: $60 \mathrm{~min}$. and $30 \mathrm{~min}$. The main reactor where the process took place was inductively heated at the desired temperature by a belt of electrical resistances. During the operation, the reactor was permanently rotated around its axis in order to allow both a better mixing between the combustion air and soil and also a better diffusion of heat inside the layers of solid material to be treated. The retention time of the material inside the reactor has been inspected both by the reactor's inclination angle and the rotation speed.

To increase the degree of homogeneity, before being fed into the plant, the contaminated soil was first pre-treated: dried at atmospheric conditions (a humid soil could produce feeding system jamming and eventual overpressure inside the combustion reactor due to water vapour release); sieved in order to eliminate the debris while the large rocks were removed manually. Table 1 shows soil physicochemical properties before and after the thermal treatment application.

The processed gas resulting from combustion was conveyed first to the post-combustion chamber where the volatilized contaminants were completely oxidized with excess air, at a temperature of about $1000^{\circ} \mathrm{C}$. The gas was then passed through the treatment fluid gas system where it was cleaned and finally released into the atmosphere.

\subsection{Soil sample collection and sample processing}

In order to identify the levels of heavy metals in soil, before and after the thermal treatment, soil samples have been grinded, sieved and dried. To bring soil samples to an analyzable form, metals were extracted in an aqueous solution according to ISO11466/1999 standards concerning "Soil quality". Analysis of the soil samples for heavy metal content was conducted using an atomic absorption spectrophotometer. $\mathrm{Zn}, \mathrm{Cu}, \mathrm{Fe}, \mathrm{Mn}, \mathrm{Ni}, \mathrm{Pb}$, $\mathrm{Cr}, \mathrm{Co}, \mathrm{Cd}, \mathrm{Hg}, \mathrm{As}$ and $\mathrm{Be}$ have been analyzed.

Table 1. Soil properties of soil before and after thermal treatment

\begin{tabular}{|c|c|c|c|c|c|}
\hline \multirow{2}{*}{ Soil } & \multirow{2}{*}{$\mathrm{pH}$} & C organic & $\mathrm{Nt}^{*}$ & $\mathrm{P}_{\mathrm{AL}} *$ & $\mathrm{~K}_{\mathrm{AL}}{ }^{*}$ \\
\hline & & \multicolumn{2}{|c|}{$\%$} & \multicolumn{2}{|c|}{$\mathrm{mg} / \mathrm{kg}$} \\
\hline Initial & 7.78 & 4.73 & 0.182 & 36 & 323 \\
\hline $\begin{array}{l}600^{\circ} \mathrm{C} ; \\
30 \mathrm{~min}\end{array}$ & 8.09 & 0.274 & 0.047 & 132 & 1078 \\
\hline $\begin{array}{l}800^{\circ} \mathrm{C} ; \\
30 \mathrm{~min}\end{array}$ & 11.69 & n.a. & 0.027 & 78 & 336 \\
\hline $\begin{array}{l}1000^{\circ} \mathrm{C} ; 30 \\
\min \end{array}$ & 11.88 & n.a. & 0.010 & 51 & 77 \\
\hline $\begin{array}{l}600^{\circ} \mathrm{C} ; \\
60 \mathrm{~min}\end{array}$ & 8.21 & 0.209 & 0.040 & 135 & 1071 \\
\hline $\begin{array}{l}800^{\circ} \mathrm{C} ; \\
60 \mathrm{~min}\end{array}$ & 12.09 & n.a. & 0.028 & 80 & 257 \\
\hline $\begin{array}{l}1000^{\circ} \mathrm{C} ; 60 \\
\min \end{array}$ & 11.37 & n.a. & 0.005 & 60 & 70 \\
\hline
\end{tabular}

* $\mathrm{P}_{\mathrm{AL}}$ represents the mobile phosphorus content; $\mathrm{K}_{\mathrm{AL}}$ is the mobile potassium content; $\mathrm{N}_{\mathrm{t}}$ is the total nitrogen; $\mathrm{n}$.a. - under detection limit.

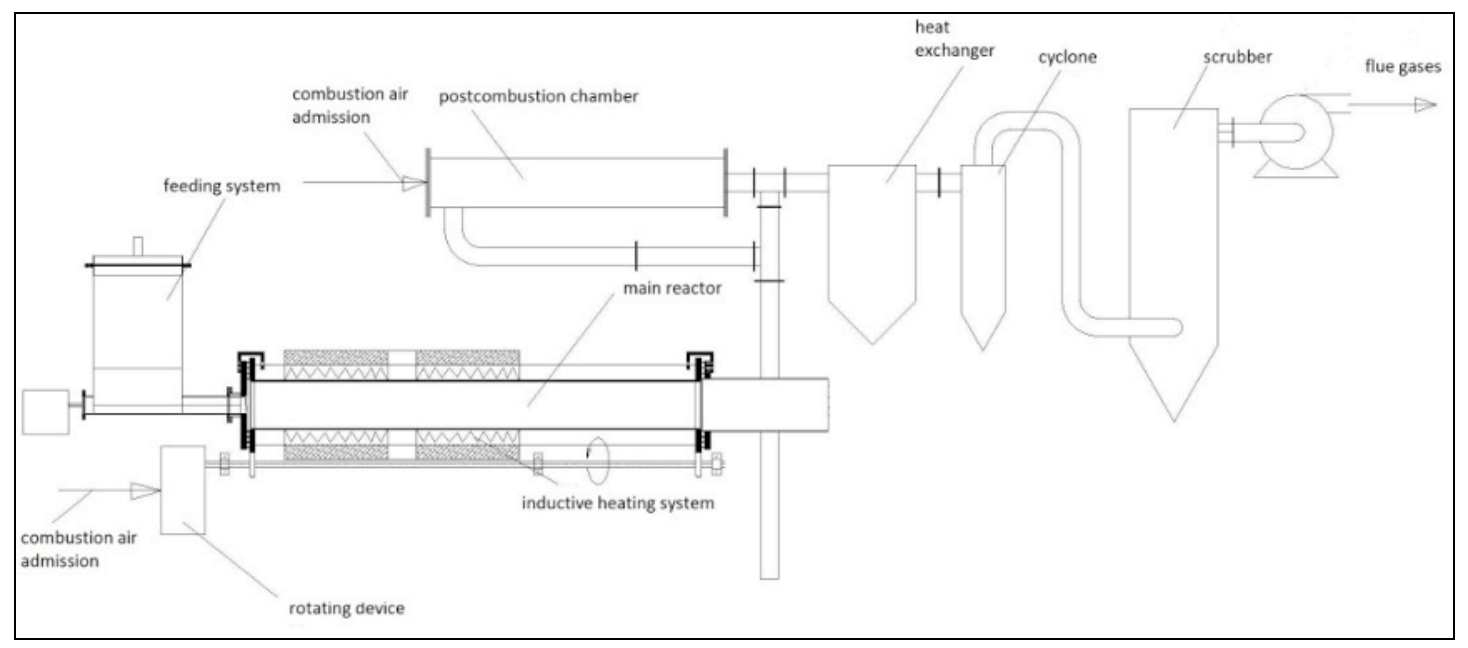

Fig. 1. Rotary kiln pilot plant incineration system

The results showed that soil had the highest concentrations of $\mathrm{Cd}, \mathrm{Pb}$ and $\mathrm{Ni}$ with mean values of $74.9 \mathrm{mg} / \mathrm{kg}_{\mathrm{dw}}, 2306 \mathrm{mg} / \mathrm{kg}_{\mathrm{dw}}$ and $214.3 \mathrm{mg} / \mathrm{kg}_{\mathrm{dw}}$, respectively. Nationally acceptable levels for intervention thresholds (sensitive use) have been exceeded by about 15 times for $\mathrm{Cd}, 23$ times for $\mathrm{Pb}$ and 1.5 times for $\mathrm{Ni}$. In this context, the authors choose to focus only $\mathrm{Cd}, \mathrm{Ni}$ and $\mathrm{Pb}$ behaviours related to thermal treatment of the polluted soil and with the associated health risks.

\subsection{Risk assessment methodology}

This work illustrates not only results relating to the efficiency of thermal treatment on removing heavy metals from soils, but also the possibility of using risk assessment as a tool for environmental managers to make decisions on risk mitigation of contaminated sites.

US EPA 98 approach (US EPA, 1989) was used for the human exposure assessment and quantification of risk from $\mathrm{Cd}, \mathrm{Ni}$ and $\mathrm{Pb}$ contaminated soils. The risk assessment tool developed within the framework of the 
RECOLAND project has been used for risk evaluation considering different exposure pathways (soil ingestion, dermal contact, vegetable ingestion and meat ingestion) according to the local context (agricultural scenario). The generally accepted lifetime health risk $\left(10^{-6}\right)$ was considered as a starting point for all discussed thermal treatment experiments.

Table 2 shows results of health risk assessment for the contaminated soil before and after soil incineration.

\section{Results and Discussion}

As expected and indicated by other authors (Van de Velden et. al. - 2007; Toledo JM et al. - 2005) the results showed that both temperature and retention time strongly influence the behavior of heavy metals in soil and also the soil's fertility due to the increment of $\mathrm{pH}$ values (alkalinity) and reduction of the total nitrogen, mobile potassium and phosphorus (see Table 1).

Fig. 2 a)-c) shows that in an oxidative atmosphere, both $\mathrm{Cd}$ and $\mathrm{Pb}$ have more or less the same vaporisation trend related to the process temperature and to the fact that the binding forces of metal ions to soil decrease with $\mathrm{pH}$ increment (Dube A. et. al. - 2001). For all three studied metals, the evaporation rate strongly increases after $800^{\circ} \mathrm{C}$. Soil retention time within the reactor did not have much influence on $\mathrm{Pb}$ concentration at $600^{\circ} \mathrm{C}$. On the contrary, the removing efficiency of $\mathrm{Cd}$ at $600^{\circ} \mathrm{C}$ increased from $51.5 \%$ for $30 \mathrm{~min}$. to $60.6 \%$ for $60 \mathrm{~min}$.

Table 2. Risk values related to contaminated soil with $\mathrm{Cd}$, $\mathrm{Ni}$ and $\mathrm{Pb}$ before and after incineration

\begin{tabular}{|c|c|c|c|c|}
\hline $\begin{array}{c}\text { Experimental } \\
\text { condition }\end{array}$ & Cd & $\mathbf{N i}$ & $\mathbf{P b}$ & $\Sigma \mathrm{Cd}, \mathrm{Ni}, \mathrm{Pb}$ \\
\hline No treatment & $\begin{array}{c}1.48 \\
\times 10^{-4} \\
\end{array}$ & $\begin{array}{c}1.65 \\
\times 10^{-5} \\
\end{array}$ & $\begin{array}{c}1.26 \\
\times 10^{-5} \\
\end{array}$ & $1.77 \times 10^{-4}$ \\
\hline $\begin{array}{l}600^{\circ} \mathrm{C} \\
30 \mathrm{~min}\end{array}$ & $\begin{array}{l}7.18 \\
\times 10^{-5}\end{array}$ & $\begin{array}{l}3.87 \\
\times 10^{-6}\end{array}$ & $\begin{array}{l}7.52 \\
\times 10^{-6}\end{array}$ & $8.32 \times 10^{-5}$ \\
\hline $\begin{array}{l}800^{\circ} \mathrm{C} ; \\
30 \mathrm{~min} .\end{array}$ & $\begin{array}{c}5.11 \\
\times 10^{-5} \\
\end{array}$ & $\begin{array}{r}4.10 \\
\times 10^{-6} \\
\end{array}$ & $\begin{array}{c}5.82 \times \\
10^{-6} \\
\end{array}$ & $6.10 \times 10^{-5}$ \\
\hline $\begin{array}{l}1000^{\circ} \mathrm{C} ; \\
30 \mathrm{~min} .\end{array}$ & $\begin{array}{r}1.54 \\
\times 10^{-5} \\
\end{array}$ & $\begin{array}{r}1.94 \\
\times 10^{-6} \\
\end{array}$ & $\begin{array}{r}1.27 \\
\times 10^{-6} \\
\end{array}$ & $1.81 \times 10^{-5}$ \\
\hline $\begin{array}{l}600^{\circ} \mathrm{C} \\
60 \mathrm{~min}\end{array}$ & $\begin{array}{l}5.84 \\
\times 10^{-5}\end{array}$ & $\begin{array}{l}3.94 \\
\times 10^{-6}\end{array}$ & $\begin{array}{l}7.68 \\
\times 10^{-6}\end{array}$ & $7.00 \times 10^{-5}$ \\
\hline $\begin{array}{l}800^{\circ} \mathrm{C} ; \\
60 \mathrm{~min} .\end{array}$ & $\begin{array}{c}3.09 \\
\times 10^{-5} \\
\end{array}$ & $\begin{array}{r}4.17 \\
\times 10^{-6} \\
\end{array}$ & $\begin{array}{r}4.52 \\
\times 10^{-6} \\
\end{array}$ & $3.96 \times 10^{-5}$ \\
\hline $\begin{array}{l}1000^{\circ} \mathrm{C} \\
60 \mathrm{~min} .\end{array}$ & $\begin{array}{l}7.72 \\
\times 10^{-6}\end{array}$ & $\begin{array}{l}1.88 \\
\times 10^{-6}\end{array}$ & $\begin{array}{l}7.02 \\
\times 10^{-7}\end{array}$ & $1.09 \times 10^{-5}$ \\
\hline
\end{tabular}

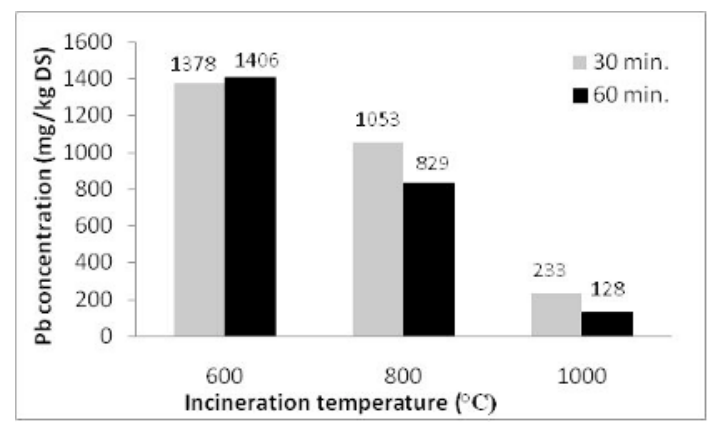

Fig. 2a. Effect of temperature and time on $\mathrm{Pb}$ concentration within soil;

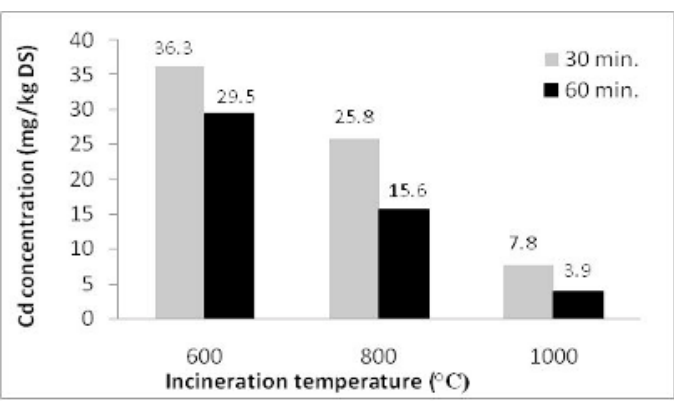

Fig 2b. Effect of temperature and time on $\mathrm{Cd}$ concentration within soil

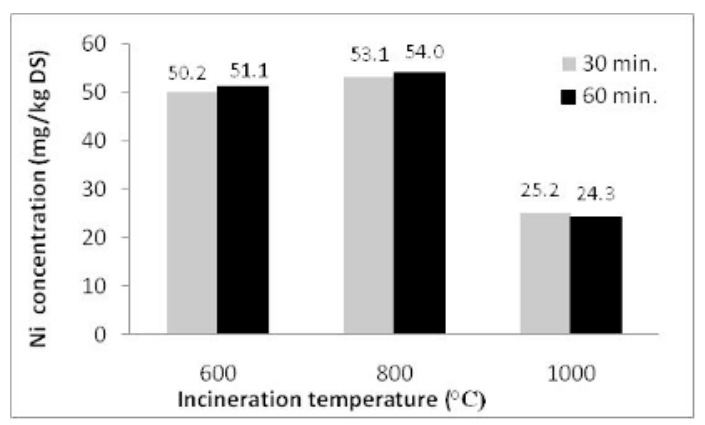

Fig 2c. Effect of temperature and time on $\mathrm{Ni}$ concentration within soil

The mobility of $\mathrm{Cd}$ in soil could be explained by the high volatility of most cadmium species formed during high temperature process (Zhang D. et. al., 2009). Even if $\mathrm{Pb}$ has a high vaporisation temperature, the presence of chlorine within the soil matrix could act as a catalyst on evaporation process of the Pb's bounded species.

Concerning the efficiency of removing $\mathrm{Cd}, \mathrm{Ni}$ and $\mathrm{Pb}$ from the contaminated soil, as expected, the best results were gained for a process temperature of $1000^{\circ} \mathrm{C}$. Regarding the residence time, for both cases $(30 \mathrm{~min}$. and $60 \mathrm{~min}$.), the removing efficiency was as follows: $\mathrm{Ni}<\mathrm{Pb}<\mathrm{Cd}$.

Considering a future use of the decontamination soil for agriculture, the authors have taken into account the nationally acceptable levels for intervention thresholds (sensitive use): $150 \mathrm{mg} \mathrm{kg}_{\mathrm{d} . \mathrm{m} .}{ }^{-1}$ for $\mathrm{Ni}, 5 \mathrm{mg} \mathrm{kg} \mathrm{d}_{\mathrm{m}}{ }^{-1}$ for $\mathrm{Cd}$ and $100 \mathrm{mg} \mathrm{kg}_{\mathrm{d} . \mathrm{m} .}{ }^{-1}$ for $\mathrm{Pb}$. In this way, it was shown that the process temperature of $1000^{\circ} \mathrm{C}$ and the residence time of $30 \mathrm{~min}$., ensured concentration levels under the permissible limits for $\mathrm{Pb}$, while the same process temperature, but a different residence time of $60 \mathrm{~min}$., guaranteed concentrations under permitted limits for both $\mathrm{Cd}$ and $\mathrm{Ni}$. If some elements, as $\mathrm{Ni}$ (at low levels), are essential trace elements for many species, in the case of $\mathrm{Cd}$ and $\mathrm{Pb}$ there is no known biological functions (Fairbrother A., et al., 2007) and they are dangerous even in small amounts. For these reasons, it is important not to consider just regulation limits in order to assess the thermal treatment removing efficiency, but also to make evaluations on risk assessment related to bottom ash heavy metals content. It is already known that heavy metals are not destroyed during incineration. They are concentrated in ash residues, or are released into the 
atmosphere. Risk assessment from $\mathrm{Cd}, \mathrm{Ni}$ and $\mathrm{Pb}$ considering the new concentration levels from the decontaminated soils (Table 2) indicated that an acceptable risk was obtained only concerning the bottom ash $\mathrm{Pb}$ concentration (process temperature of $1000^{\circ} \mathrm{C}$ and the residence time of $30 \mathrm{~min}$ ). The assessments were made considering the initial agricultural scenario according to the local context. The present work pointed out that, if incineration is the single alternative for contaminated land management, a regulatory approach alone is not sufficient to take into account by the decision-makers, but also an appropriatecontrol of environmental pollution (emissions, fly ash, and bottom ash).

\section{Conclusion}

The present work exemplifies how the assessment of the human health effects could really become important criteria for decision-makers. The presented approach could be adopted for optimizing soil treatment methodologies not only related to the efficiency of removal, but also with regard to the impact on human health.

\section{Acknowledgements}

The work was supported by the National Authority for Scientific Research - Romania, under the Sectorial Operational Programme "Increase of Economic Competitiveness" POS-CCE-A2-O2.1.2.-2009-2, RECOLAND project (ID519), SMIS-CSNR: 11982, Nb. 182/18.06.2010 (2010-2013).

\section{References}

Anne Fairbrother, Randall Wenstel, Keith Sappington,
William Wood, 2007. Framework for metals risk assessment, Ecotoxicology and environmental Safety 68 (2007) 145-227.

EEA (European Environmental Agency), 2007. Progress in management of contaminated sites. Report CSI 015, Copenhagen, European Environment Agency; 2007.

ISO 11466, 1999. Soil quality. Extraction of trace elements soluble soluble in aqua regia, Romanian Standards Association.

McLean JE and Bledsoe BE. EPA Raport: Ground water issue - Behavior of metals in soil. 1992; 12; EPA/540/S-92/018.

Szanto PM, Micle V, Prodan CV. Study of soil qualiy in Copsa Mica area with the aim of their remediation. ProEnvironment 2011; 4; 169-173.

Toledo JM, Corella J, Corella LM. The partition- ning of heavymetal in incineration of sludges and waste in a bubbling fluidized bed -2 . Interpretation of results with a conceptual model. J of Hazardous Materials 2005; B126; 158 -168.

US EPA (United States, Environmental Protection Agency), 1989. Risk Assessment Guidance for Superfund, Volume I, Human Health Evaluation Manual (Part A). Report EPA/540/1-89/002. (December 1989). < http://www.epa.gov/oswer /riskassessment/ragsa/pdf/rags_a.pdf $>$.

Van de Velden M, Dewil R, Baeyens J, Josson L, Lanssens $\mathrm{P}$. The distribution of heavy metals during fluidized bed combustion sludge (FBSC). J of Hazardous Materials 2008; 151; 96-102.

Zhang D, Kong H, Wu D, He S, Hu Z, Dai L. Impact of Pyrolysis treatment on heavy metals in sediment. Soil and Sediment Contamination; 2009; 18; 745-765 